\title{
Does Immigration Stimulate Foreign Trade? Evidence from Sweden
}

\author{
Andreas Hatzigeorgiou \\ Ministry for Foreign Affairs of Sweden
}

\begin{abstract}
Foreign born people are uniquely qualified to stimulate trade between their present country of residence and the country in which they were born. This study provides an empirical investigation of the link between migration and trade flows for Sweden. Trade and migration data for Sweden and 180 partner countries between 2002 and 2007 are used to estimate an augmented gravity model. The results show a statistically strong, positive and robust link between migration and increased trade flows. The analysis derives the effect from the ability of foreignborn people to improve the flow of information between Sweden and their former home countries. This study argues, in light of the findings, that immigration can be used as an instrument for increased foreign trade and that the issue of migration thus deserves increased focus in trade policy and economic policy.
\end{abstract}

- JEL Classification: F10, F22, F14

- Key Words: Trade, Migration, Gravity Models

\section{Introduction}

Globalization has linked countries more closely together. New technology makes transport within and between countries easier. Multilateral and regional trade agreements have further lowered or eliminated trade barriers. However, despite globalization and liberalization, foreign trade still involves considerable costs. To trade with other countries, firms need to acquire general import and export skills. Firms also need to acquire substantial specific information about the

*Corresponding address: Andreas Hatzigeorgiou; The author is International Trade Economist at the Ministry for Foreign Affairs of Sweden, e-mail: andreas.hatzigeorgiou@foreign.ministry.se.

@2010-Center for International Economics, Sejong Institution, Sejong University, All Rights Reserved. 
relevant foreign market. Such information can range from specific economic, social and political conditions to legislation and regulations, norms of business behavior, culture and language. A lack of relevant information therefore creates thresholds that may hurt international trade.

Immigrants have a good knowledge of the business culture, politics, religion and language of their former home countries. Their contact networks put them in a particularly good position to personally stimulate trade with their countries of origin. Moreover, they can serve to show the way for other firms that want to engage in trade with the former home countries of people born abroad. This applies in particular to markets in countries with weak institutions, where information demanded by foreign trading companies may be in short supply.

There is empirical evidence suggesting that migrants increase trade between their present countries of residence and their countries of birth. However, analyses have focused on investigating how immigration affects trade in large countries, such as the US, or on an aggregate level for a group of rich countries, such as OECD members. There is lack of evidence from small and open economies. Since small open economies are generally more dependent on foreign trade and, moreover, are those where immigrants make up a considerable share of the population, this lack of evidence constitutes a large gap in the understanding of the trade and migration link.

The objective of this study is to estimate the relationship between immigration and foreign trade in Sweden. With its export oriented economy, where trade constitutes $90 \%$ of GDP, the country is a paragon of the small open economy. Further, it has been an important host of immigration since the 1930s.

Trade and migration data for Sweden and 180 partner countries between 2002 and 2007 are used to estimate an augmented gravity model. The study is organized as follows. Section II gives background information on migration and illustrates relevant developments globally and in Sweden. Section III describes the theoretical link between immigration and foreign trade in greater detail and examines previous research in the area. Section IV presents the data and method of analysis. Section $\mathrm{V}$ analyses the results and performs several robustness checks. The conclusions are presented and their policy implications are discussed in Section VI.

\section{Migration: Background and Trends}

People's decisions to migrate from their countries of birth are explained by 
various factors. Social, political and economic circumstances play a major role. The causes operate on both the demand side and the supply side. The former category includes wage differentials or other factors that reflect differences in relative - real or perceived - living standards between countries. On the supply side, apart from labour market variables, demography and circumstances of a social and political nature operate Puri (Puri, 2008).

Migrants - people who live in countries other than their countries of birth - today make up about three per cent of the world's population. This is twice as high a proportion as in 1960 . The picture becomes even more striking when we take into account that the global population has more than doubled over the same period, from 3 billion in 1960 to 6.7 billion in 2008. The proportion of migrants has increased dramatically in relatively developed countries, from $3.4 \%$ in 1960 to $9.5 \%$ in 2005 (OECD, 2007). The migrant stock has therefore seen substantial growth over a prolonged period. The UN estimates that the rate of growth in the total number of voluntary migrants worldwide peaked in 2000-2005 at around $2.2 \%$ per year. ${ }^{1}$ Growth is now concentrated in the more developed countries. Around 210 million migrants are expected in $2010,57 \%$ of whom are expected to settle in high-income countries (Zukang, 2009).

The face of migration has changed over the years. Countries that were once typical emigration countries are now major recipients of migrants born in other countries. The distribution of number of immigrants - like the number of emigrants - varies widely from country to country and region to region. Certain countries have a large number of immigrants but almost no emigrants or vice versa.

Sweden has long been a major migration country. The shift from an emigration to immigration country took place in the 1930s, and the trend has continued since then. Over the past five years, the population of Sweden has increased by over 242000 . Immigration accounted for $77 \%$ of this increase. According to the Swedish Migration Board, a total of 99,485 people immigrated to Sweden in 2007. This is the largest number of people to immigrate during a single year since measurements began in 1875 . The percentage of migrants relative to the domestically-born population has also increased dramatically ever since the World War II. In 1940, foreign-born people made up one per cent of the total population. In 1970 that figure had risen to around seven per cent, while the current figure is about 13\%. Table 1 contains information on Sweden's largest immigrant stocks.

${ }^{1}$ The rate of growth is slightly lower - $1.8 \%$ - when the number of refugees is included in the estimate. 
Table 1. Sweden's Immigrant Stocks (2007)

\begin{tabular}{clrrlr}
\hline Rank & Source Country & Stock & Rank & Source country & Stock \\
\hline 1 & Finland & 178,179 & 16 & Syria & 18,229 \\
2 & Iraq & 97,513 & 17 & China & 16,013 \\
3 & Serbia/Montenegro & 72,939 & 18 & USA & 15,309 \\
4 & Poland & 58,180 & 19 & Romania & 15,214 \\
5 & Iran & 56,516 & 20 & India & 14,415 \\
6 & Bosnia-Herzegovina & 55,713 & 21 & Hungary & 14,057 \\
7 & Denmark & 45,941 & 22 & Vietnam & 13,184 \\
8 & Germany & 45,034 & 23 & Russia & 12,748 \\
9 & Norway & 44,590 & 24 & Ethiopia & 11,783 \\
10 & Turkey & 38,158 & 25 & Greece & 10,833 \\
11 & Chile & 28,019 & 26 & Afghanistan & 10,605 \\
12 & Lebanon & 22,967 & 27 & South Korea & 9,958 \\
13 & Thailand & 22,926 & 28 & Estonia & 9,800 \\
14 & Somalia & 21,597 & 29 & Colombia & 9,681 \\
15 & UK and Ireland & 18,486 & 30 & Philippines & 8,095 \\
\hline
\end{tabular}

Source: Statistics Sweden (2008); author's calculations.

\section{Theory and Previous Research}

There has been impressive progress in lowering and eliminating trade barriers since World War II. The average tariff level applied to industrial goods in the world's most developed countries is now barely 5\%. It is even lower in the rich OECD countries, where the average applied tariff rate for industrial goods is $2.8 \%$. The developing countries have slightly higher tariffs, averaging around $10 \%$ for industrial goods, which is a low level in historical terms (UNCTAD/WTO, 2009). Despite this, international trade still involves considerable costs (see e.g., Anderson and Van Wincoop, 2004; Hummels and Klenow, 2005; Melitz, 2008). Firms that want to import or export goods or services face substantial fixed costs. Apart from transport costs, they need to obtain general trade skills and specific knowledge of the foreign market. Many of these trade costs are driven by a lack of information ex ante.

The information required to engage in foreign trade is expensive to obtain. It is difficult to obtain reliable information about unfamiliar foreign markets whose business culture, language, regulatory system and institutions differ from those of the home country. Information barriers drive up the costs of importing and exporting. Knowledge about distribution chains is one example of this kind of barrier. Burstein et al. (2003) demonstrated that half the net prices of selected 
goods in the United States corresponded to distribution costs. Bradford and Lawrence (2003) derived a large proportion of the net price differentials in different countries from differences in distribution costs.

Foreign-born residents possess a unique knowledge of their countries of birth. This comprises knowledge of people in the country, their preferences, culture, price awareness and inclination to follow trends. They also have a unique sense of norms, politics and history. Migrants can bridge cultural divides and pass on information that noticeably reduces costs of distribution, marketing and other such matters to which firms are otherwise obliged to allocate resources. People born abroad often know how business contracts are drawn up in their countries of birth, and how negotiating processes should be designed to achieve the desired result.

Information barriers can be exacerbated by weak institutions. Anderson and Marcouiller (2002) showed that institutional quality influences the efficiency of trade transactions. Weak institutions influence trade costs and, indirectly, business profits. Bandyopadhyay and Roy (2007) showed that corruption and a lack of compliance with business contracts generally lead to higher levels of protectionism and poorer economic openness. This hinders foreign trade. Here, too, people born abroad can play an important role as they are often aware of ways of circumventing corruption.

There is evidence suggesting that migrants increase trade between their present countries of residence and their countries of birth. Gould (1994) found a statistically significant link between immigrants to the United States and US trade with their countries of origin. Head and Ries (1998) found a similar link for Canada, estimating an import elasticity at $0.3 \%$ and export elasticity at $0.1 \%$. Girma and Yu (2002) demonstrated a positive link between exports and immigration from countries outside the former British Empire, although no significant link could be demonstrated for migration within the former Empire. Further evidence of a positive migrant impact on trade was provided by Herander and Saavedra (2005), Bandyopadhyay et al. (2006), Dunlevy (2006) and Jansen and Piermartini (2009). However, the estimated effect varies in different studies: from around $0.1 \%$ to $3.5 \%$ increased trade as a result of a $10 \%$ increase in the total migrant stock in the country concerned.

There are no broad data for individual developing countries. However, Ehrlich and Canavire Bacarreza (2006) found a positive and significant correlation for Bolivia.

A number of recent studies have attempted to estimate a more general 
correlation. Using OECD statistics, Lewer (2006) found that immigration stimulates bilateral trade between a cross-section of industrial countries and immigrant source countries. Felbermayr and Toubal (2008) and Lewer and Van den Berg (2009) used a similar sample of countries, but expands the analysis to dismantle the channels through which migration may affect trade. Both confirm a positive impact of migrants on trade. Lewer and Van den Berg conclude, inter alia, that migrants facilitate trade by creating and participating in networks that span across destination and native countries. Bettin and Turco (2008) used a similar selection of countries and also investigated the effect in different sectors. They found that the migrant trade effect is ambiguous across sectors. Hatzigeorgiou (2010) evaluated the link globally based on a large number of industrialized and developing countries. The positive effect of migrants on trade could be confirmed on the global level as well.

\section{The Empirical Model}

Both Sweden's foreign trade and number of immigrants have increased in recent years. In 2002 Sweden had imports totaling USD 66.5 billion. Exports amounted to USD 82 billion. Five years later, total imports were at USD 150 billion and exports USD 166 billion. Imports had therefore increased by approximately $125 \%$ and exports had doubled between 2002 and 2007. The number of foreign-born residents rose by approximately 230,000 , an increase of about $23 \%$.

Is there a link between the number of people born abroad and Swedish trade with countries of origin, suggesting that immigration stimulates trade? If so, how extensive is the impact on trade? To answer this question, a gravity model for international trade is used. This model is the industry standard for quantifying the

Table 2. Immigrants in Sweden and Foreign Trade (2002-2007)

\begin{tabular}{|c|c|c|c|c|c|c|c|c|c|}
\hline & \multicolumn{3}{|c|}{$\begin{array}{c}\text { Number of Immigrants } \\
\text { (thousands) }\end{array}$} & \multicolumn{3}{|c|}{$\begin{array}{c}\text { Exports } \\
\text { (million USD) }\end{array}$} & \multicolumn{3}{|c|}{$\begin{array}{c}\text { Imports } \\
\text { (million USD) }\end{array}$} \\
\hline & 2002 & 2007 & $\overline{\text { Change }}$ & 2002 & 2007 & $\overline{\text { Change }}$ & 2002 & 2007 & Change \\
\hline World & 971 & 1,198 & $23 \%$ & 82,000 & 166,000 & $102 \%$ & 66,500 & 150,000 & $126 \%$ \\
\hline Africa & 56 & 79 & $40 \%$ & 981 & 3,021 & $208 \%$ & 145 & 248 & $71 \%$ \\
\hline America & 79 & 87 & $11 \%$ & 12,000 & 18,100 & $51 \%$ & 4,347 & 7,373 & $70 \%$ \\
\hline Asia & 191 & 345 & $80 \%$ & 10,400 & 19,200 & $85 \%$ & 6,493 & 17,800 & $174 \%$ \\
\hline Europe & 642 & 684 & $7 \%$ & 57,700 & 124,000 & $115 \%$ & 55,300 & 124,000 & $124 \%$ \\
\hline Pacific & 3 & 4 & $15 \%$ & 991 & 2,145 & $116 \%$ & 243 & 453 & $86 \%$ \\
\hline
\end{tabular}

Source: Statistics Sweden (2009) and WDI (2008); author's calculations. 
impact of trade costs on international trade flows. In its simplest form the model postulates that the volume of trade, $X_{i j}$, between the countries (objects) $i$ and $j$ is determined by the economic size (mass) of the countries, designated $Y$, the distance between them, designated $d_{i j}$, and the gravitational constant $g$, thus

$$
X_{i j}=g \frac{Y_{i} Y_{j}}{d_{i j}}
$$

The first economic application of the typical gravity law given in the above approach is ascribed to Tinbergen (1962). When first introduced, the model lacked a satisfactory theoretical basis. Anderson (1979), Helpman and Krugman (1985), Bergstrand (1989) and Deardorff (1998) have later strengthened the theoretical foundations of the model. The general assumptions are complete product specialization between countries, consumer preferences of CES type, and symmetrical trade costs between trading partners. Deardorff (1998) derived the model on the basis of a factor proportion explanation. Anderson and Van Wincoop (2003) further justified the model on the basis of assumptions on monopolistic competition and product differentiation. The theoretical basis of the gravity model is now regarded as robust.

The basic gravity specification is generally augmented by geographical and historical information about the countries and the relationship between them to capture other significant trade costs. This is motivated by the strong correlation with transport and information costs. Limao and Venables (2001) demonstrated that infrastructure has a powerful influence on volumes of trade. Most studies also agree that the geographical location and characteristics of countries affect trade costs and foreign trade. The geographical distance between countries is reflected in higher bilateral trade costs. Hence, distance has a negative influence on trade (Rauch, 2001). Language is another important factor, as countries that share a language avoid trade costs associated with communication problems, translation of necessary documents, etc. Countries that have a shared history can also escape indirect trade costs in various ways (Melitz, 2008). Equations that include historical and cultural variables generally fall into the category of "augmented gravity models" and are estimated by

$$
X_{i j}=\alpha+\beta_{1} \ln Y_{j}+\beta_{2} \ln Y_{i}+\beta_{3} \ln d_{i j}+\beta_{4} \text { pop }_{j}+\beta_{5} \text { pop }_{i}, \quad+\mathbf{G} \gamma_{i}+\mathbf{H} \delta_{k}+\varepsilon_{i j}
$$

where $X_{i j}$ represents exports from country $i$ to country $j, Y$ corresponds to each 
country's GDP and $d_{i j}$ is the distance between the countries. The column vectors usually contain a number $(i)$ of geographical variables, such as indicators for whether the countries share a national border, have the same official language or lack access to a coastline of their own, and a number $(k)$ of historical and cultural variables, indicating whether the country is a former colony, any colonial relationship between the countries, etc.

As previously discussed, it is assumed that information barriers are an important determinant of bilateral trade costs. People who are resident in countries other than their countries of birth have the potential to reduce these costs and thus facilitate trade between their current home countries and the countries where they were born. To capture this line of argument, the gravity model is augmented by a control variable for the number of people born in country $j$ but resident in country $i$. Hence, the relevant specification for this study is

$$
\begin{aligned}
\ln X_{i j t}= & \alpha+\beta_{1} \ln m_{j i t}+\beta_{2} \ln Y_{j t}+\beta_{3} \ln Y_{j t}+\beta_{4} \ln d_{i j}, \\
& +\beta_{4} \ln p o p_{i t}+\beta_{5} \ln p o p_{j t}+\mathbf{G} \gamma_{i}+\mathbf{H} \delta_{k}+\varepsilon_{i j t}
\end{aligned}
$$

where the dependent variable $X_{i j}$ represents Swedish exports (or imports) to (or from) country $j$ at time $t . m_{i j t}$ represents the number of immigrants from country $j$ who are resident in Sweden - the immigrant stock - at time $t . Y_{i}$ and $Y_{j}$ correspond to Sweden's and each partner country's GDP. The distance variable $d_{i j}$ measures the distance between Sweden and the trading partners by means of a weighted average between Stockholm and the most populous city in each partner country. The size of Sweden's population and the population of each partner country is included in $p_{p} p_{i t}$ and $p o p_{j t}$. The vector variable $\mathbf{G}$ controls for the effect of a shared border between Sweden and $j$ and whether $j$ lacks access to a coastline of its own, while $\mathbf{H}$ controls for EU and WTO membership respectively. In light of the EU enlargement process, which as late as in 2007 included several new members, the EU indicator variable is unity for the year for which the country became a member and all following years. The indicator variable for WTO membership is intended to control to some extent for a country's trade policy. ${ }^{2}$

The years concerned are 2002-2007. The basic specification is estimated for 180 countries with which Sweden conducts trade. Table 3 shows that all regions of the world are represented.

${ }^{2}$ However, a better measure of trade policy is included in a later specification. 
Table 3. Countries in the Sample

\begin{tabular}{|c|c|c|c|}
\hline Afghanistan & Philippines & Latvia & San Marino \\
\hline Albania & Finland & Lebanon & Sao Tome and Principe \\
\hline Algeria & France & Liberia & Saudi Arabia \\
\hline Angola & Gabon & Libya & Switzerland \\
\hline Antigua and Barbuda & Gambia & Lithuania & Senegal \\
\hline United Arab Emirates & Georgia & Luxemburg & Seychelles \\
\hline Argentina & Ghana & Madagascar & Sierra Leone \\
\hline Armenia & Greece & FYROM & Singapore \\
\hline Australia & Grenada & Malawi & Slovakia \\
\hline Azerbaijan & Guatemala & Malaysia & Slovenia \\
\hline Bahamas & Guinea & Maldives & Somalia \\
\hline Bahrain & Guinea-Bissau & Mali & Spain \\
\hline Bangladesh & Guyana & Malta & Sri Lanka \\
\hline Barbados & Haiti & Morocco & St Kitts och Nevis \\
\hline Belgium & Honduras & Marshall Islands & St Lucia \\
\hline Belize & Hong Kong & Mauretania & St Vincent and Grenadine \\
\hline Benin & India & Mauritius & UK \\
\hline Bermuda & Indonesia & Mexico & Sudan \\
\hline Bhutan & Iraq & Mozambique & Surinam \\
\hline Bolivia & Iran & Moldavia & Swaziland \\
\hline Bosnia-Herzegovina & Ireland & Mongolia & Syria \\
\hline Botswana & Island & Myanmar & Tadzhikistan \\
\hline Brazil & Israel & Namibia & Tanzania \\
\hline Brunei & Italy & Netherlands & Chad \\
\hline Bulgaria & Jamaica & Nepal & Thailand \\
\hline Burkina Faso & Japan & Nicaragua & Czech Republic \\
\hline Burundi & Jordan & Niger & Togo \\
\hline Central Africa Republic & Yugoslavia & Nigeria & Trinidad and Tobago \\
\hline Chile & Cambodia & Norway & Tunisia \\
\hline Colombia & Cameron & New Zeeland & Turkey \\
\hline Costa Rica & Canada & Oman & Turkmenistan \\
\hline Cyprus & Cap Verde & Austria & Germany \\
\hline Denmark & Kazakhstan & Pakistan & USA \\
\hline Djibouti & Kenya & Panama & Uganda \\
\hline Dominica & China & Papua New Guinea & Ukraine \\
\hline Dominican Republic & Kirgizstan & Paraguay & Hungary \\
\hline Ecuador & Kiribati & Peru & Uruguay \\
\hline Egypt & Congo & Poland & Uzbekistan \\
\hline Equatorial Guinea & Korea, North- & Portugal & Vanuatu \\
\hline El Salvador & Korea, South- & Qatar & Venezuela \\
\hline Cote d'Ivoire & Croatia & Romania & Vietnam \\
\hline Eritrea & Cuba & Rwanda & Belarus \\
\hline Estonia & Kuwait & Russia & Yemen \\
\hline Ethiopia & Laos & Solomon Islands & Zambia \\
\hline Fiji & Lesotho & Samoa & Zimbabwe \\
\hline
\end{tabular}


The estimation that follows also include region specific fixed effects and year dummies. ${ }^{3}$ The former are useful since they capture region-specific influences, such as factor endowments, which could affect trade flows between Sweden and other countries. $^{4}$

If trade leads to increased familiarity between Sweden and its trading partners, this could theoretically influence the cost of emigration to Sweden. Potential endogeneity of the migrant stock variable, arising from reverse causality with respect to trade, implies correlation between the migrant stock variable and the error term in the structural equation. In the estimated equations, however, it is assumed that the direction of causation is from immigration to trade, and not vice versa. The basis for this conclusion is threefold.

First, nowhere in the huge literature on international migration and development is existing trade flows put forward as a significant determinant of migration. The economic theory of migration postulates that the decision to migrate follows a willingness to maximize utility, and therefore, emigration will follow if economic benefits associated with emigration outweigh the costs (Brettell and Hollifield, 2008; Lee and Hernandez, 2009). Rational individuals will make a decision to emigrate with the goal of maximizing the "revenue" of emigration. ${ }^{5}$ Clearly, the economic advantage anticipated by these people is a far more compelling proximate cause of their decision to come to Sweden than the existence of trade relations between their countries and Sweden. In fact, when sociologists and anthropologists have investigated this issue on the micro-level, they have not found

\footnotetext{
${ }^{3}$ Regions are Africa, America, Asia, Europe, and the Pacific.

${ }^{4}$ Anderson and Van Wincoop (2003) suggest estimating gravity models using a country-specific fixed effects approach, mainly to control for "multilateral trade resistance." Indeed, their approach has had a significant impact in the literature, and today estimating gravity equations with country-specific fixed effects is the industry standard. However, the issue has not been conclusively resolved, and advances in the discourse on the gravity model have challenged the Anderson and van Wincoop approach. Moenius et al. (2009) argue specifically that the Anderson van Wincoop method suffers from severe limitations. They argue that the correlation between multilateral resistances and consumer price indices is either insignificant or negative, in direct opposition to theory. In sum, they conclude: "the theoretical emperor is dressed in elegant silk, but the empirical emperor does not wear any clothes yet, and consequently the race for solving the border puzzle is still on." Hence, applying a country-specific fixed effects approach would not necessarily improve estimation. This, in addition to the fact that there is a substantial benefit in exploiting cross-sectional information in the data, led me to not adopt a country-specific fixed effects approach.

${ }^{5}$ It is obvious that the large number of Iraqi immigrants that have moved to Sweden since 2001 have done so mainly to enhance their overall "utility," meaning raising their standard of living. The same thing is true for Polish immigrants, who have been coming to Sweden in large numbers since Poland's accession to the EU.
} 
that preexisting trade flows between the host country and the source country were a factor influencing the decision to emigrate (Gould, 1994). When asked, people answered that they moved to a place where their standard of living would be significantly higher and where some fellow countrymen already lived. In the case of Sweden, this is likely to be true as well. And, there is no evidence suggesting that immigrants coming to Sweden make their decision based on preexisting bilateral trade with Sweden.

Second, immigration from most of the countries in the sample is subject to binding quotas. Preference is given to family reunification. These two aspects make immigration much more of an exogenously determined variable than bilateral trade flows.

Finally, other scholars have provided important evidence of the direction of causation, supporting the theory that migration causes trade. Dunlevy and Hutchinson (1999) provide evidence in this direction. Hatzigeorgiou (2010) finds that migrant stocks are exogenous to levels of bilateral trade. There is no reason to believe that the direction of causation would run in the opposite direction in the case of Sweden. ${ }^{6}$

\section{Data and Estimation Results}

Trade data are taken from the UN Comtrade database and cover the years 20022007. Statistics for the number of foreign-born people from each country of origin come from Statistics Sweden. Information on the GDP and population of trading partners comes from the World Bank's World Development Indicators. The geographical indicators come from the Centre d'Etudes Prospective et d'Informations Internationales.

\section{A. Results for Aggregate Trade}

The gravity equation is first estimated without the migrant stock, that is, it contains Sweden's and the partner country's GDPs, distance from Sweden, as well as the population size of Sweden and the partner country, together with indicators

\footnotetext{
${ }^{6}$ The most common approach to address the problem of endogeneity is to use an instrumental variable approach. An instrumental variable approach was not adopted by this study, as explained, since theory and all existing evidence point to the direction of causality going from migration to trade. Further, although there have been some attempts to find an instrument for migration in cases where migration is suspected to be endogenous, no study has yet implemented an instrumental variable approach that satisfy the appropriate identifying conditions.
} 
Table 4a. Effect of Immigrants on Sweden's Exports

\begin{tabular}{|c|c|c|c|c|c|}
\hline & \multicolumn{5}{|c|}{ Exports } \\
\hline & I & II & III & IV & $\mathrm{V}$ \\
\hline & OLS & OLS & Panel & Tobit & Panel \\
\hline \multirow[t]{2}{*}{ Immigrants } & & $0.690^{* * *}$ & $0.667^{* * *}$ & $0.666^{* * *}$ & $0.579^{* * *}$ \\
\hline & & 0.031 & 0.063 & 0.055 & 0.063 \\
\hline \multirow[t]{2}{*}{ GDP Sweden } & -5.876 & -5.267 & -3.197 & -3.181 & -2.187 \\
\hline & 17.128 & 12.958 & 5.542 & 5.740 & 4.697 \\
\hline \multirow[t]{2}{*}{ GDP Partner } & 0.052 & $0.352^{* * *}$ & $0.373^{* * *}$ & $0.373^{* * *}$ & $0.402^{* * *}$ \\
\hline & 0.050 & 0.037 & 0.073 & 0.068 & 0.087 \\
\hline \multirow[t]{2}{*}{ Distance } & $-1.022^{* * *}$ & $-0.555^{* * *}$ & $-0.642^{* * *}$ & $-0.642^{* *}$ & $-0.527^{* *}$ \\
\hline & 0.172 & 0.133 & 0.240 & 0.292 & 0.251 \\
\hline \multirow[t]{2}{*}{$\begin{array}{l}\text { Population } \\
\text { Sweden }\end{array}$} & 85.191 & 75.684 & $74.863^{*}$ & $74.618^{*}$ & $74.649^{* *}$ \\
\hline & 133.436 & 101.154 & 43.815 & 44.533 & 38.113 \\
\hline \multirow[t]{2}{*}{$\begin{array}{l}\text { Population } \\
\text { Partner }\end{array}$} & $0.213^{* * *}$ & $-0.347^{* * *}$ & $-0.362^{* * *}$ & $-0.361^{* * *}$ & $-0.411^{* * *}$ \\
\hline & 0.070 & 0.055 & 0.110 & 0.101 & 0.130 \\
\hline \multirow[t]{2}{*}{ Adjacency } & 0.424 & $-1.257^{* * *}$ & $-1.406^{* * *}$ & -1.400 & $-0.989^{* *}$ \\
\hline & 0.458 & 0.190 & 0.420 & 0.984 & 0.454 \\
\hline \multirow[t]{2}{*}{ Landlocked } & $-1.553^{* * *}$ & $-0.580^{* * *}$ & $-0.572^{* *}$ & $-0.573^{* *}$ & $-0.745^{* *}$ \\
\hline & 0.168 & 0.141 & 0.288 & 0.267 & 0.317 \\
\hline \multirow[t]{2}{*}{$\begin{array}{l}\text { European } \\
\text { Union }\end{array}$} & $1.442^{* * *}$ & $1.126^{* * *}$ & 0.007 & 0.009 & -0.060 \\
\hline & 0.242 & 0.173 & 0.089 & 0.170 & 0.085 \\
\hline WTO member & $0.520^{* * *}$ & $0.864^{* * *}$ & $0.970^{* * *}$ & $0.965^{* * *}$ & \\
\hline \multirow[t]{2}{*}{ Trade policy } & 0.189 & 0.183 & 0.354 & 0.277 & 0.226 \\
\hline & & & & & 0.162 \\
\hline \multirow[t]{2}{*}{ Business climate } & & & & & -0.292 \\
\hline & & & & & 0.203 \\
\hline \multirow[t]{2}{*}{$\begin{array}{l}\text { Corruption } \\
\text { (absence) }\end{array}$} & & & & & 0.082 \\
\hline & & & & & 0.107 \\
\hline \multirow[t]{2}{*}{ Constant } & -136.779 & -127.127 & -136.237 & -135.755 & $-140.048^{* *}$ \\
\hline & 200.401 & 152.100 & 66.352 & 66.826 & 58.493 \\
\hline Time fixed effects & yes & yes & yes & yes & yes \\
\hline $\begin{array}{l}\text { Region fixed } \\
\text { effects }\end{array}$ & yes & yes & yes & yes & yes \\
\hline $\mathrm{N}$ & 797 & 793 & 793 & 793 & 708 \\
\hline Adj $R^{2}$ & 0.592 & 0.759 & 0.754 & & 0.746 \\
\hline Log-likelihood & & & & -969.733 & \\
\hline
\end{tabular}

Note: Robust standard errors below coefficients. ${ }^{* * * \Gamma^{* *} \Gamma^{*} \text { indicates level of significance at the } 1 / 5 / 10 \%}$ significance levels. 
Table 4b. Effect of Immigrants on Sweden's Imports

\begin{tabular}{|c|c|c|c|c|c|}
\hline & \multicolumn{5}{|c|}{ Imports } \\
\hline & I & II & III & IV & $\mathrm{V}$ \\
\hline & OLS & OLS & Panel & Tobit & Panel \\
\hline \multirow[t]{2}{*}{ Immigrants } & & $0.944^{* * *}$ & $0.888^{* * *}$ & $0.875^{* * *}$ & $0.792^{* * *}$ \\
\hline & & 0.044 & 0.089 & 0.085 & 0.099 \\
\hline \multirow[t]{2}{*}{ GDP Sweden } & -10.002 & -5.567 & -2.222 & -3.544 & -4.307 \\
\hline & 25.570 & 21.156 & 10.463 & 9.788 & 10.263 \\
\hline \multirow[t]{2}{*}{ GDP Partner } & -0.067 & $0.341^{* * *}$ & $0.397^{* * *}$ & $0.395^{* * *}$ & $0.308^{* *}$ \\
\hline & 0.062 & 0.052 & 0.110 & 0.103 & 0.135 \\
\hline \multirow[t]{2}{*}{ Distance } & $-0.698^{* *}$ & -0.066 & -0.135 & -0.139 & 0.277 \\
\hline & 0.277 & 0.225 & 0.389 & 0.442 & 0.353 \\
\hline \multirow[t]{2}{*}{ Population Sweden } & 116.395 & 77.053 & 65.934 & 71.553 & 88.021 \\
\hline & 201.077 & 165.673 & 82.212 & 75.938 & 80.593 \\
\hline \multirow[t]{2}{*}{ Population Partner } & $0.465^{* * *}$ & $-0.297^{* * *}$ & $-0.353^{* *}$ & $-0.351^{* *}$ & -0.245 \\
\hline & 0.092 & 0.081 & 0.170 & 0.153 & 0.204 \\
\hline \multirow[t]{2}{*}{ Adjacency } & 0.613 & $-1.699^{* * *}$ & $-1.847^{* * *}$ & -1.785 & $-1.058^{* *}$ \\
\hline & 0.553 & 0.285 & 0.551 & 1.488 & 0.543 \\
\hline \multirow[t]{2}{*}{ Landlocked } & $-2.061^{* * *}$ & $-0.732^{* * *}$ & $-0.724^{*}$ & $-0.710^{*}$ & $-0.865^{* *}$ \\
\hline & 0.233 & 0.206 & 0.436 & 0.404 & 0.444 \\
\hline \multirow[t]{2}{*}{ European Union } & $2.138^{* * *}$ & $1.691^{* * *}$ & $0.407^{* *}$ & 0.427 & $0.471^{* *}$ \\
\hline & 0.308 & 0.251 & 0.173 & 0.285 & 0.191 \\
\hline \multirow[t]{2}{*}{ WTO member } & $1.367^{* * *}$ & $1.878^{* * *}$ & $1.896^{* * *}$ & $1.851^{* * *}$ & \\
\hline & 0.305 & 0.275 & 0.478 & 0.419 & \\
\hline \multirow[t]{2}{*}{ Trade policy } & & & & & -0.456 \\
\hline & & & & & 0.331 \\
\hline \multirow[t]{2}{*}{ Business climate } & & & & & 0.286 \\
\hline & & & & & 0.452 \\
\hline \multirow{2}{*}{$\begin{array}{l}\text { Corruption } \\
\text { (absence) }\end{array}$} & & & & & $0.523^{* *}$ \\
\hline & & & & & 0.215 \\
\hline \multirow[t]{2}{*}{ Constant } & -187.529 & -136.699 & -130.439 & -135.178 & -169.951 \\
\hline & 303.000 & 249.076 & 123.812 & 113.929 & 121.673 \\
\hline Time fixed effects & yes & yes & yes & yes & yes \\
\hline $\begin{array}{l}\text { Region fixed } \\
\text { effects }\end{array}$ & yes & yes & yes & yes & yes \\
\hline $\mathrm{N}$ & 793 & 793 & 793 & 793 & 708 \\
\hline $\operatorname{Adj} R^{2}$ & 0.720 & 0.719 & 0.719 & & 0.720 \\
\hline Log-likelihood & & & & -1372.924 & \\
\hline
\end{tabular}

Note: Robust standard errors below coefficients. $* * * * * / *$ indicates level of significance at the $1 / 5 / 10 \%$ significance levels. 
of whether the country borders on Sweden or whether it lacks access to a coastline of its own. The results for exports are presented in Table $4 \mathrm{a}$ and for imports in Table $4 \mathrm{~b}$. Most of the coefficients have the expected sign.

Three regressions each are conducted for exports and imports using the basic model, including the migrant stock as a control variable (Columns II-IV). The partner country's GDP has a positive and significant influence on trade. The distance from Sweden, as expected, has a negative link with exports and it too is strongly significant. Being landlocked is negatively correlated with trade flows. The size of relevant coefficients largely follows the literature, with a particularly large negative link being evident for distance from Sweden. On average, Sweden's trade with other EU countries is higher than with non-Member States. Sweden's trade with members of the WTO is on average higher than for other countries.

The results clearly demonstrate that foreign-born people have a positive and statistically strong influence on bilateral trade between Sweden and foreign-born residents' former home countries. In addition to OLS estimation, a regression is carried out for pooled panels. OLS estimation has proved to lead to incorrect results when the trade statistics include zero flows between trade partners. This has been demonstrated by Santos Silva and Tenreyro (2006) and by Helpman et al. (2008), for example. There are alternative solutions for correcting this problem. Alternative estimation methods are proposed by Eaton and Tamura (1994) and Santos Silva and Tenreyro (2006). Helpman et al. (2008) propose a method based on two-stage estimation (2SLS).

In this case, however, the potential problem of zero flows in trade is not considered a problem. Only a handful of such observations exist in the data set. Nonetheless, an alternative method of estimation - Tobit estimation - is adopted for safety's sake. If the problem of zero flows in the trade statistics causes misleading results, there should be a substantial difference between the point estimates obtained from panel data regression and Tobit estimation.

The link is both economically and statistically significant. Exports and imports alike show strong elasticity with respect to migrants. The migrant effect outweighs the link between trade and the partner country's GDP. For exports, the link indicates an average increase of seven per cent from a ten per cent increase in the number of people born abroad. For imports the suggested effect is even greater. The effect is very stable across the different estimation methods. The estimate changes only marginally with method.

Other control variables are influenced by the inclusion of the migrant stock. The 
effect of the distance from Sweden diminishes considerably for exports, as does the effect of being landlocked. Other factors, such as the partner country's GDP and the effect of bordering on Sweden, increase in significance. Whether the partner country is an EU country has no significance for exports, and its significance for imports is ambiguous. This differs from the results generated by estimating the basic gravity specification, which may be explained by the fact that a majority of foreign-born people in Sweden - 684,000 in 2007- are originally from other countries in Europe. The EU effect probably captures the effect that migration has on bilateral trade between Sweden and the countries that the majority of people born abroad originally come from. It therefore declines when the migrant stock is explicitly controlled for.

The results corroborate the argument that people born abroad stimulate trade between Sweden and their former home countries. The scope of the migrants' impact is both economically and statistically significant. The results are robust across different estimation methods and hold for alternative selections, e.g., removing the ten countries with which Sweden has least trade or the countries that have very few members of their native population living in Sweden, and removing trading partners that are EU members.

It is interesting that imports prove to be particularly influenced by the migrant stock. The coefficient is about $30 \%$ greater for imports than for exports. Part of the explanation may be that foreign-born people are quite simply in a better position to lower or eliminate information barriers that are important for imports but less important for exports. In other words, it is possible that firms that import goods benefit more from the unique knowledge that people born abroad possess about their countries of birth than export-oriented firms. Another explanation is that the impact on the "extensive margin" of imports is greater than the corresponding impact on exports. In other words, the results may indicate that the presence of people born abroad increases the probability of more importers becoming established relative to export-oriented firms. Another cause of the difference between the migrant effect with respect to exports and with respect to imports is that it is reasonable to assume - particularly in a country such as Sweden - that it is easier to start up import businesses than businesses exporting to the foreign markets in which many foreign-born people have their roots. Finally, it may be worth mentioning that the difference could also be attributable to an inherent preference effect among foreign-born residents to consume goods produced in their countries of birth. However, the theory assumes that the preference effect is 
negligible if the share of immigrants is small compared with the overall domestic population. Also, any such effect is unlikely to last as most goods are substitutable (see e.g., Dunlevy and Hutchinson, 1999; Girma and Yu, 2000). Finally, while the preference effect only has a potential impact on imports, better information channels have the potential to increase both imports and exports. It is therefore more likely that the former effects in combination drive the results and that migrant elasticity is quite simply greater for imports than for exports.

\section{B. Extended Model}

Previous research has demonstrated a negative correlation between institutional quality and countries' foreign trade (e.g. Bandyopadhyay and Roy, 2007). The specification is therefore augmented to take this into account. The column vector $\mathbf{H}$ contains three control variables intended to reflect the institutional quality of the partner country. These are trade policy $\left(\tau_{j}\right)$, business climate $\left(\phi_{j}\right)$ and incidence of corruption $\left(\kappa_{j}\right)$. The data come from the World Heritage Foundation, which in turn estimates its index on the basis of statistics from the World Bank, the WTO, the US Department of Commerce, and Transparency International.

Trade policy is an index based on countries' trade-weighted average tariff $\left(t_{j}\right)$ plus the incidence of non-tariff barriers to trade $\left(n_{j}\right)$ expressed as

$$
\tau_{j}=\left[\left(\frac{\hat{t_{j}}-t_{j}}{\hat{t_{j}-\tilde{t}_{j}}}\right) \cdot 100\right]-n_{j}
$$

where $\hat{t}_{j}$ and $\tilde{t}_{j}$ represent the upper and lower bounds of the partner country's tariffs in per cent; $\tilde{t}_{j}>0$ and $\hat{t}_{j}<0.5$. Using both qualitative and quantitative measurements, $n_{j}$ is estimated for product groups and services over various sectors in country $j$. The existence of non-tariff barriers to trade leads to a lower degree of freedom of trade. This variable is a more direct and therefore better measure of a country's economic openness to the world around it than, for example, the indicator variable for WTO membership. Freedom of trade is measured on a scale ranging from 0 to 100 , and the coefficient for this variable is therefore expected to be positively related to trade between Sweden and the partner country concerned.

Business climate is another index that is assumed to have a positive influence on trade. This index builds on ten quantitative indicators, including the number of days it takes to start a business in the partner country, how many documents are required for the business to start operations, etc. Each factor is converted to a scale of $0-100\left(b_{j}\right)$ after which an average value for all factors is calculated $\left(\bar{b}_{j k}\right)$. The 
business climate in the country is then estimated by

$$
\phi_{j}=\frac{\left(50 \cdot \bar{b}_{j}\right)}{b_{j}}
$$

Incidence of corruption is synonymous with freedom from corruption and is based on the Transparency International index. The measure reflects people's perceptions of corruption in particular countries. A low score corresponds to high levels of corruption and vice versa. This variable is therefore expected to have a positive influence on bilateral trade. ${ }^{7}$

The gravity specification including the migrant stock and the above institutional variables is estimated for 173 countries. The results are presented in Column V in Tables 4a-b The strong migrant effect persists even after variables for trade policy, business climate and incidence of corruption are included. As previously, the effect is confirmed at a high statistical significance level. However, the coefficients are slightly lower than when estimating the previous specification. The estimated migrant effect, however, is marginally lower for this specification - only $13 \%$ for exports and eleven per cent for imports. A one per cent increase in the number of people born abroad has an average positive effect on exports to the foreign-born residents' countries of birth of about $0.6 \%$. For imports the average effect is close to $0.8 \%$.

The estimated impact of trade policy and business climate in the partner country appears to be insignificant for both exports and imports. For incidence of absence of corruption, a significant positive correlation is observed with higher imports only. These findings differ somewhat from studies focusing on the significance of an open trade policy, business climate and low corruption for international trade. When the migrant stock is included in the specification, these factors do not seem to have any particular influence on bilateral trade flows. The reason may be that immigrants effect on trade between Sweden and other countries diminishes the importance of low trade barriers, a good business climate and absence of corruption in partner countries.

The extended model includes both standard gravity control variables, variables included in most augmented models, as well as variables to control for trade policy, overall business climate and institutional quality. Notwithstanding this, there might

\footnotetext{
${ }^{7}$ For more detailed information on these institutional variables and the underlying methodology, see the relevant data source.
} 
be unobserved factors that affect Swedish trade with other countries. The data allows for a way of controlling for such unobserved factors, by estimating the models with the inclusion of trade flows from previous years. Thus, as a robustness check, the models are estimated with the lagged dependent variable, $X_{i j t-1}$. Hence, the extended model to be estimated is

$$
\begin{aligned}
\ln X_{i j t}= & \alpha+\lambda X_{i j t-1}+\beta_{1} \ln m_{j i t}+\beta_{2} \ln Y_{j t}+\beta_{3} \ln Y_{j t}+\beta_{4} \ln d_{i j} \\
& +\beta_{4} \ln p o p_{i t}+\beta_{5} \ln p o p_{j t}+\boldsymbol{G} \gamma_{i}+\mathbf{H} \delta_{k}+\varepsilon_{i j t}
\end{aligned}
$$

This approach follows Gould (1994) and Head and Ries (1998), who interpret it as a partial adjustment model. Table 5 displays the results of regressions in which the lagged dependent variable was included and year dummies were dropped. The immigrant effect on trade in this model corresponds to the direct effect plus the indirect effect through the lagged dependent variables, which is $m_{j i t}(1-\lambda)^{-1}$. Although a lagged dependent variable approach contains several challenges, including increased data requirements, it is evident that the key results are robust to inclusion of lagged dependent variables. The implied elasticity of immigration is generally intact using the basic model with lagged dependent variables, 0.6 for exports and 0.9 for imports. For the extended model, the estimated immigrant elasticity is 0.4 for exports and 0.7 for imports. While these coefficients are slightly lower, they still remain significant. It should be noted that one fifth of the observations had to be dropped in order to perform this robustness test.

\section{Interaction Effects}

It is probable that the impact of migration on bilateral trade, even if substantial and statistically significant at the aggregate level, differs from country to country. Since the migrant effect derives from lower trade costs via the information channel, it is likely that the effect differs between countries in which the costs to foreign companies of obtaining necessary information vary. For example, it is possible that the migrant effect is influenced by countries' level of development and geographical location. To control for these aspects, the immigrant stock variable is interacted with variables. The previous results have shown that the migrant effect is robust to the inclusion of trade policy, business climate and incidence of corruption, as well as inclusion of lagged dependent variables. No radical results could be substantiated for the individual variables included in the extended model. However, it is likely that the migrant effect interacts with these factors so that the 
Table 5. Sensitivity Analysis of Immigrants' Effect on Trade Using Lagged Dependent Variable

\begin{tabular}{|c|c|c|c|c|}
\hline & \multicolumn{2}{|c|}{ Exports } & \multicolumn{2}{|c|}{ Imports } \\
\hline & I & II & IIII & IV \\
\hline & Basic & Extended & Basic & Extended \\
\hline \multirow[t]{2}{*}{ Lagged dep. var. } & $0.822^{* * *}$ & $0.858^{* * *}$ & $0.723^{* * *}$ & 0.739 \\
\hline & 0.036 & 0.025 & 0.036 & 0.038 \\
\hline \multirow[t]{2}{*}{ Immigrants } & $0.114^{* * *}$ & $0.055^{* *}$ & $0.242^{* * *}$ & $0.180^{* * *}$ \\
\hline & 0.032 & 0.023 & 0.049 & 0.045 \\
\hline \multirow[t]{2}{*}{ GDP Sweden } & -4.075 & 0.602 & -1.695 & -6.045 \\
\hline & 5.510 & 4.575 & 10.305 & 10.075 \\
\hline \multirow[t]{2}{*}{ GDP Partner } & 0.027 & -0.016 & 0.068 & -0.018 \\
\hline & 0.028 & 0.024 & 0.043 & 0.067 \\
\hline \multirow[t]{2}{*}{ Distance } & $-0.138^{*}$ & $-0.196^{* * *}$ & -0.109 & -0.053 \\
\hline & 0.078 & 0.062 & 0.144 & 0.124 \\
\hline \multirow[t]{2}{*}{ Population Sweden } & 31.234 & -11.089 & -7.779 & 30.490 \\
\hline & 43.101 & 35.039 & 79.326 & 77.968 \\
\hline \multirow[t]{2}{*}{ Population Partner } & -0.008 & 0.048 & -0.044 & 0.075 \\
\hline & 0.039 & 0.036 & 0.066 & 0.100 \\
\hline \multirow[t]{2}{*}{ Adjacency } & -0.182 & -0.128 & $-0.449^{* *}$ & $-0.368^{* *}$ \\
\hline & 0.116 & 0.091 & 0.193 & 0.181 \\
\hline \multirow[t]{2}{*}{ Landlocked } & -0.105 & $-0.168^{*}$ & -0.150 & -0.273 \\
\hline & 0.096 & 0.087 & 0.177 & 0.173 \\
\hline \multirow[t]{2}{*}{ European Union } & $0.193^{* * *}$ & $0.125^{* *}$ & $0.469^{* * *}$ & $0.297^{* * *}$ \\
\hline & 0.075 & 0.058 & 0.125 & 0.115 \\
\hline \multirow[t]{2}{*}{ WTO member } & 0.196 & & $0.474^{* *}$ & \\
\hline & 0.136 & & 0.203 & \\
\hline \multirow[t]{2}{*}{ Trade policy } & & $0.295^{* * *}$ & & 0.148 \\
\hline & & 0.107 & & 0.224 \\
\hline \multirow[t]{2}{*}{ Business climate } & & -0.050 & & 0.573 \\
\hline & & 0.170 & & 0.427 \\
\hline \multirow[t]{2}{*}{ Corruption (absence) } & & 0.096 & & 0.275 \\
\hline & & 0.085 & & 0.189 \\
\hline \multirow[t]{2}{*}{ Constant } & -43.800 & 22.883 & 28.082 & -35.864 \\
\hline & 64.457 & 51.861 & 117.485 & 115.696 \\
\hline Time fixed effects & no & no & no & no \\
\hline Region fixed effects & yes & yes & yes & yes \\
\hline $\mathrm{N}$ & 625 & 562 & 625 & 562 \\
\hline $\operatorname{Adj} R^{2}$ & 0.934 & 0.958 & 0.899 & 0.907 \\
\hline
\end{tabular}

Note: Robust standard errors below coefficients. ${ }^{* * *} /^{* * *} \rho^{*}$ indicates level of significance at the $1 / 5 / 10 \%$ significance levels. 
migrant effect (on trade) operates in combination with these country-specific characteristics. The effect of an open trade policy, a good business climate and a lack of corruption can thus indirectly influence trade via their influence on the migrant effect.

The results in Table 6 show that the migrant effect on imports is stronger for countries with an open trade policy. Swedish imports are favored by the presence of foreign-born people in Sweden, provided that the countries of origin have an open trade policy. However, for exports, no significant effect is registered.

A good business climate in the partner country increases the migrant effect on Swedish exports. Foreign-born residents whose former home countries have a favorable business climate are therefore in a good position to benefit Swedish exports to these countries. There is no statistically significant interaction effect between the number of foreign-born residents and a low incidence of corruption in the partner country.

The interesting conclusion from these interactions is that the degree of openness in the trade policy and business climate of the partner countries influences trade with Sweden beyond the direct channels. Trade policy and business climate have an indirect impact on the migrant effect and thereby significance for bilateral trade.

Information failures are more common in poor countries. Since migration is primarily assumed to exercise a positive influence on trade through lower information barriers, it is probable that the development level of the partner country interacts negatively with the migrant stock. Panel B of Table 6 shows the results from a regression including the migrant stock and an indicator variable for the country's level of development. ${ }^{8}$ The results show that the level of development of the partner country influences the migrant effect for Swedish exports but not for imports. The results also strengthen the hypothesis that the migrant effect is stronger in poor countries than in rich countries. This is explained by the fact that people originating from rich countries have less to contribute in terms of lower trade costs and trade promotion than people originating from poor countries, where the formal channels for obtaining the information needed for successful trade are more limited.

Panel $\mathrm{C}$ includes interaction variables between the migrant stock and different continents. The purpose of this is to assess whether the migrant effect for Swedish

\footnotetext{
${ }^{8} \mathrm{~A}$ developing country is defined as a country that does not reach the World Bank's threshold for being regarded as a high-income country (GDP per capita over USD 7 000).
} 
Table 6. Immigration and Sweden's Foreign Trade - Interaction Effects

\begin{tabular}{|c|c|c|c|c|c|c|}
\hline & \multicolumn{3}{|c|}{ Exports } & \multicolumn{3}{|c|}{ Imports } \\
\hline Panel A & OLS & Panel & Tobit & OLS & Panel & Tobit \\
\hline \multirow[t]{2}{*}{ Immigrants x Trade Policy } & -0.104 & -0.096 & -0.097 & 0.007 & $0.419^{*+1}$ & 0.421 \\
\hline & 0.073 & 0.080 & 0.064 & 0.103 & 0.119 & 0.111 \\
\hline \multirow[t]{2}{*}{ Immigrants $\mathrm{x}$ Business Climate } & $0.271^{* *}$ & $0.344^{* * *}$ & $0.356^{* * *}$ & -0.184 & 0.228 & $0.247^{*}$ \\
\hline & 0.119 & 0.087 & 0.082 & 0.189 & 0.169 & 0.143 \\
\hline \multirow[t]{2}{*}{ Immigrants x Corruption (absence) } & -0.018 & -0.039 & -0.036 & 0.067 & -0.015 & -0.013 \\
\hline & 0.048 & 0.040 & 0.036 & 0.077 & 0.073 & 0.062 \\
\hline Adj $R^{2}$ & 0.697 & 0.595 & & 0.651 & 0.580 & \\
\hline Log-likelihood & & & -1061.931 & & & -1543.891 \\
\hline \multicolumn{7}{|l|}{ Panel B } \\
\hline \multirow[t]{2}{*}{ Immigrants x Developing } & 0.042 & $0.096^{* * *}$ & $0.092^{* * *}$ & -0.062 & -0.072 & -0.064 \\
\hline & 0.051 & 0.034 & 0.031 & 0.080 & 0.068 & 0.051 \\
\hline $\mathrm{N}^{\cdots}$ & $\overline{1}, \overline{0} \overline{2} 5^{-}$ & $1,025^{-}$ & $\overline{1}, \overline{0} \overline{2} 5^{-}$ & $1,025^{-}$ & $1,0 \overline{25}$ & $1,025^{-}$ \\
\hline Immigrants x Asia & 0.080 & 0.119 & 0.153 & 0.125 & 0.185 & 0.228 \\
\hline \multirow[t]{2}{*}{ Immigrants x America } & 0.098 & 0.016 & 0.018 & $0.386 * * *$ & 0.112 & 0.089 \\
\hline & 0.083 & 0.183 & 0.170 & 0.119 & 0.235 & 0.250 \\
\hline \multirow[t]{2}{*}{ Immigrants x Africa } & -0.116 & -0.003 & -0.011 & -0.074 & -0.377 & -0.392 \\
\hline & 0.107 & 0.171 & 0.165 & 0.134 & 0.240 & 0.244 \\
\hline \multirow[t]{2}{*}{ Immigrants x Pacific } & $0.902^{* * *}$ & $0.881^{* *}$ & $0.864^{* * *}$ & $0.963 * * *$ & $0.770^{*}$ & $0.718^{\#}$ \\
\hline & 0.102 & 0.348 & 0.307 & 0.134 & 0.415 & 0.447 \\
\hline $\mathrm{N}^{-\cdots}$ & $\overline{1}, 0 \overline{2} 5$ & 1,025 & $\overline{1}, \overline{0} \overline{2} 5$ & $1,025^{-}$ & 1,025 & 1,025 \\
\hline Adj $R^{2}$ & 0.592 & 0.588 & & 0.572 & 0.572 & \\
\hline Log-likelihood & & & -1394.248 & & & -1852.983 \\
\hline
\end{tabular}

Note: Robust standard errors below coefficients. $\left.\left.{ }^{* * *}\right|^{* *}\right|^{*}$ indicates level of significance at the $1 / 5 / 10 \%$ significance levels. 
foreign trade differs depending on the regional location of the partner country. Compared with migration from the rest of Europe, the migration effect on trade is not significantly affected by whether the country of origin is in Africa, Asia or America. For the Pacific Region - the smallest group of countries - in contrast, there is a positive interaction effect for both exports and imports. The interaction is particularly strong for Swedish exports to the Pacific countries.

Other interaction effects were investigated as well, e.g., in regard to migration and geographic distance from Sweden. Since theory postulates that migrants may facilitate trade by reducing information frictions between countries, it could be expected that the effect is stronger for trade with distant partner countries. However, interacting the migrant stock with geographic distance did support this hypothesis.

\section{Test of the Information Channel Hypothesis Using Disaggregate Trade}

The results show a strong and positive correlation between the number of foreign-born people and Swedish trade with the countries from which they originate. The theory is based on the assumption that this effect derives from the superior inherent knowledge that foreign-born people possess about their former home countries, which lowers and eliminates information frictions between the countries. This in turn leads to lower trade costs and more bilateral trade. If this is so, it is reasonable to assume a stronger migrant effect for trade in goods that are particularly dependent on low information barriers. Such goods are distinguished by unique qualities. For example, they lack a reference price, i.e., the price of the goods cannot be determined without reference to more detailed information about brand, origin, producer, etc.

To test the strength of the hypothesis that the positive migrant effect on trade operates through the information channel, foreign trade data are divided -following Rauch (1999) - into three categories: differentiated goods, reference-priced goods and homogeneous goods. The latter two groups are assumed here to be homogeneous. Regressions are performed separately for these groups. If the theory of the significance of the information channel is correct, a larger migrant effect will be expected for exports in differentiated goods than for trade in homogeneous goods. No particular attention is given to imports in this test. If this test would make sense in regard to imports, the model would have to include emigrants from Sweden living in other countries. The results are presented in Table 7.

The results confirm that it is primarily via the information channel that migration 
Table 7. Effect of Immigration on Sweden's Trade in Differentiated Versus Homogenous Goods

\begin{tabular}{|c|c|c|c|c|c|c|c|c|}
\hline & \multicolumn{4}{|c|}{ Differentiated Goods } & \multicolumn{4}{|c|}{ Homogenous Goods } \\
\hline & \multicolumn{2}{|c|}{$\begin{array}{l}\text { I } \\
\text { Exports }\end{array}$} & \multicolumn{2}{|l|}{$\begin{array}{l}\text { II } \\
\text { Imports }\end{array}$} & \multicolumn{2}{|c|}{$\begin{array}{l}\text { III } \\
\text { Exports }\end{array}$} & \multicolumn{2}{|l|}{$\begin{array}{l}\text { IV } \\
\text { Imports }\end{array}$} \\
\hline \multirow{2}{*}{ Immigrants } & 0.578 & & 0.768 & & 0.529 & & 0.843 & \\
\hline & 0.074 & & 0.110 & & 0.072 & & 0.141 & \\
\hline \multirow[t]{2}{*}{ GDP Sweden } & -1.091 & & -11.667 & & -10.433 & ** & -18.758 & \\
\hline & 5.571 & & 9.327 & & 5.136 & & 13.109 & \\
\hline \multirow[t]{2}{*}{ GDP Partner } & 0.406 & $* * *$ & 0.380 & *** & 0.432 & $* * *$ & 0.304 & \\
\hline & 0.095 & & 0.137 & & 0.104 & & 0.193 & \\
\hline \multirow[t]{2}{*}{ Distance } & -0.568 & ** & 0.691 & & -0.675 & ** & -0.299 & \\
\hline & 0.233 & & 0.492 & & 0.327 & & 0.544 & \\
\hline \multirow[t]{2}{*}{ Population Sweden } & 70.323 & & 116.539 & & 124.066 & $* * *$ & 168.434 & * \\
\hline & 43.903 & & 72.331 & & 39.626 & & 101.063 & \\
\hline \multirow[t]{2}{*}{ Population Partner } & -0.403 & $* * *$ & -0.304 & & -0.417 & $* * *$ & -0.210 & \\
\hline & 0.142 & & 0.205 & & 0.155 & & 0.289 & \\
\hline \multirow[t]{2}{*}{ Adjacency } & -1.072 & ** & -1.465 & ** & -1.316 & ** & -1.467 & ** \\
\hline & 0.484 & & 0.653 & & 0.626 & & 0.730 & \\
\hline \multirow[t]{2}{*}{ Landlocked } & -1.090 & $* * *$ & -1.016 & * & -1.046 & ** & -0.207 & \\
\hline & 0.321 & & 0.547 & & 0.474 & & 0.647 & \\
\hline \multirow[t]{2}{*}{ European Union } & -0.216 & ** & 0.240 & & 0.077 & & 0.668 & *** \\
\hline & 0.107 & & 0.165 & & 0.089 & & 0.243 & \\
\hline \multirow[t]{2}{*}{ Trade policy } & 0.307 & & 0.258 & & 0.136 & & -0.279 & \\
\hline & 0.241 & & 0.329 & & 0.164 & & 0.577 & \\
\hline \multirow[t]{2}{*}{ Business climate } & -0.009 & & 0.538 & & 0.358 & & 1.063 & $*$ \\
\hline & 0.317 & & 0.434 & & 0.238 & & 0.638 & \\
\hline \multirow[t]{2}{*}{ Corruption (absence) } & -0.050 & & 0.138 & & 0.039 & & 0.652 & ** \\
\hline & 0.155 & & 0.210 & & 0.128 & & 0.319 & \\
\hline \multirow[t]{2}{*}{ Constant } & -137.009 & ** & -198.806 & $*$ & -204.026 & $* * *$ & -265.792 & $*$ \\
\hline & 66.507 & & 108.251 & & 59.618 & & 152.715 & \\
\hline Time fixed effects & yes & & yes & & yes & & yes & \\
\hline Region fixed effects & yes & & yes & & yes & & yes & \\
\hline $\mathrm{N}$ & 601 & & 601 & & 601 & & 601 & \\
\hline Adj R2 & 0.714 & & 0.728 & & 0.723 & & 0.638 & \\
\hline
\end{tabular}

Note: Robust standard errors below coefficients. ${ }^{* * *} \rho^{* *} \rho^{*}$ indicates level of significance at the $1 / 5 / 10 \%$ significance levels.

influences trade. For exports, the migrant effect is clearly higher for differentiated goods than for homogeneous goods, by around $9 \%$. This makes it clear that the unique knowledge of foreign-born people about their countries of birth is important to lower information barriers and hence trade costs, which in turn lead to increased 
trade.

\section{Conclusion and Final Remarks}

Globalization has increased the need to study different sources of trade costs. Although factors that hinder access to information about trade and foreign markets are a clear source of trade costs, this aspect has not been studied to any great extent.

People from foreign backgrounds have a good knowledge of the business culture, politics, religion and language of their former home countries. Their contact networks put them in a particularly good position to facilitate trade with their countries of origin. Moreover, they can serve to show the way for other firms that want to engage in trade with the former home countries of people born abroad. This is particularly true of closed markets in countries with weak institutions, where information demanded by foreign trading companies is in short supply.

This study has investigated whether the link between migration and increased trade can be substantiated for Sweden. Trade and migration data for Sweden and 180 partner countries between 2002 and 2007 have been used to estimate an augmented gravity model. The results show a statistically strong, positive and robust migrant effect on Swedish foreign trade. A 10\% increase in the total migrant stock from a specific country results, on average, in an increase of around $6 \%$ in exports to the country concerned. Imports increase by around nine per cent.

It is worth stressing that the migrant effect outweighs the estimates made of effects for other countries and at aggregate levels. The link is even stronger for the goods that Sweden mainly exports to other countries, namely, differentiated goods, whose success in foreign markets is highly dependent on information about the specific qualities of the goods. This strengthens the argument that the positive migrant effect on trade is due to foreign-born people improving the flow of information between Sweden and their former home countries.

The results are robust to a range of specifications and estimation methods. The impact on Swedish exports to and imports from partner countries owes more to the number of immigrants from these countries than to factors such as the trade policy or business climate of the partner country. Sweden can increase its market access to strategic markets by increasing the number of Swedish residents born in those countries. Further, improved conditions for Sweden's immigrants to create and participate in trade networks can also facilitate trade with other countries. This may 
be a superior approach compared with, say, working for trade liberalization in specific partner countries.

Nonetheless, the significance of increased economic openness and an improved business climate in the partner countries cannot be wholly disregarded. Even if the significance of these factors in a traditional sense appears to have only a limited direct influence on trade, there are indirect channels that are important to take into account. For example, an advantageous business climate in the partner country has a positive influence on trade by reinforcing the effect that migration, in turn, has on trade. There are therefore still major incentives for partner countries to improve their business climate with a view to increasing trade.

The study argues for an increased focus on migration in trade policy and economic policy in small open economies, such as Sweden. Immigration can be used as an instrument for increased foreign trade. In Sweden, the discussion of immigration and its economic effects is often defined as an issue that is mainly related to the labor market. This study has shown that immigration also influences trade with other countries.

\section{Acknowledgement}

The author is thankful for comments and suggestions provided by Robert M. Stern, Anders Boman, and two anonymous referees. The findings, interpretations, and conclusions expressed in this paper are entirely those of the author. They do not represent the view of the Swedish Ministry for Foreign Affairs or the Swedish Government.

Received 27 October 2009, Revised 27 January 2010, Accepted 1 February 2010

\section{References}

Anderson, J. (1979), “A Theoretical Foundation for the Gravity Equation”, The American Economic Review, Vol. 69, pp. 106-116.

Anderson, J., Marcouiller, D. (2002), "Insecurity and the Pattern of Trade: An Empirical Investigation", Review of Economics and Statistics, Vol. 84, pp. 342-352.

Anderson, J., Van Wincoop, E. (2003), "Gravity with Gravitas: A Solution to the Border Puzzle", American Economic Review, Vol. 93, pp. 170-192.

Anderson, J., Van Wincoop, E. (2004), “Trade Costs”, Journal of Economic Literature, Vol. 42, pp. 691-751. 
Bandyopadhyay, S., Coughlin, C., and Wall, H. (2006), "Ethnic Networks and US Exports", Working Paper Series, 2005-069D, Federal Reserve Bank of St. Louis.

Bandyopadhyay, S., Roy, S. (2007), "Corruption and Trade Protection: Evidence from Panel Data”, Working Paper Series, 2007-022A, Federal Reserve Bank of St. Louis.

Bergstrand, J. (1989), "The Generalized Gravity Equation, Monopolistic Competition, and the Factor-Proportions Theory in International Trade", The Review of Economics and Statistics, Vol. 71, pp. 143-153.

Bettin, G., Turco, A. (2008), "A Cross Country View on South-North Migration and Trade", Mimeo, Hamburg Institute of International Economics and Department of Economics, Universita Politencia della Marche.

Bradford, S., Lawrence, R. (2003), Paying the Price: The Cost of Fragmented International Markets, Washington, DC, Institute of International Economics.

Brettell, C., Hollifield, J. (2008), "Migration Theory: Talking across Disciplines", Migration Theory: Talking Across Disciplines (Ed.) C. Brettell and J. Hollifield, New York, Routledge, pp. 1-30.

Burstein, A., Neves, J., Rebelo, S. (2003), "Distribution Costs and Real Exchange Rate Dynamics during Exchange-Rate-Based Stabilizations", Journal of Monetary Economics, Vol. 50, pp. 1189-1214.

Deardorff, A. (1998), "Determinants of Bilateral Trade: Does Gravity Work in a NeoClassical Framework?", The Regionalization of the World Economy (Ed.) J. Frankel. Chicago, University of Chicago Press. 7.

Dunlevy, J. (2006), "The Influence of Corruption and Language on the Pro-trade Effect of Immigrants: Evidence from the American States", Review of Economics and Statistics, Vol. 88, pp. 182-186.

Dunlevy, J., Hutchinson, W. (1999), "The Impact of Immigration on American Import Trade in the Late Nineteenth and Early Twentieth Centuries", The Journal of Economic History, Vol. 59, pp. 1043-1062.

Eaton, J., Tamura, A. (1994), "Bilateralism and Regionalism in Japanese and US Trade and Foreign Direct Investment Patterns", Journal of the Japanese and International Economies, Vol. 8, pp. 478-510.

Ehrlich, L., Canavire Bacarreza, G. (2006), "The Impact of Migration on Foreign Trade: A Developing Country Approach", Latin American Journal of Economic Development, Vol. 6, pp. 125-146.

Felbermayr, J., Toubal, F. (2008), "Revisiting the Trade-Migration Nexus: Evidence from New OECD Data", Working Paper, University of Stuttgart-Hohenheim and Paris School of Economics.

Girma, S., Yu, Z. (2002), "The Link between Immigration and Trade: Evidence from the United Kingdom", Review of World Economics, Vol. 138, pp. 1610-2878.

Gould, D. (1994), "Immigrant Links to the Home Country: Empirical Implications for US Bilateral Trade Flows", The Review of Economics and Statistics, Vol. 76, pp. 302-316.

Hatzigeorgiou, A. (2008), "Migration as Trade Facilitation: Assessing the Links between International Trade and Migration", Working Paper, The University of Michigan. 
Head, K., Ries, J. (1998), "Immigration and Trade Creation: Econometric Evidence from Canada", Canadian Journal of Economics, Vol. 31, pp. 47-62.

Head, K., Ries, J. (2007), “Do Trade Missions Increase Trade?”, Sauder School of Business Working Paper, University of British Columbia, Vancouver.

Helpman, E., Krugman, P. (1985), Market Structure and Foreign Trade, Cambridge, MA, MIT Press.

Helpman, E., Melitz, M., and Rubinstein, Y. (2008), "Estimating Trade Flows: Trading Partners and Trading Volumes", Quarterly Journal of Economics, Vol. 123, pp. 441-487.

Herander, M., Saavedra, L. (2005), "Exports and the Structure of Immigrant-Based Networks: The Role of Geographic Proximity", Review of Economics and Statistics, Vol. 87, pp. 323-335.

Hummels, D., Klenow, P. (2005), "The Variety and Quality of a Nation's Exports", American Economic Review, pp. 704-723.

Jansen, M., Piermartini, R. (2009), "Temporary Migration and Bilateral Trade Flows", The World Economy, Vol. 32, pp. 735-753.

Lee, C., Hernandez, M. (2009), "Theories of Immigration: An Analysis of Textbooks on Human Behavior and the Social Environment", Journal of Human Behavior in the Social Environment, Vol. 19, pp. 663-674.

Lewer, J. (2006), "The Impact of Immigration on Bilateral Trade: OECD Results from 1991-2000", Southwestern Economic Review, Vol. 33, pp. 9-22.

Lewer, J., Van den Berg, H. (2009), "Does Immigration Stimulate International Trade? Measuring the Channels of Influence", The International Trade Journal, Vol. 23, pp. 187-230.

Limao, N., Venables, A. (2001), "Infrastructure, Geographical Disadvantage, Transport Costs, and Trade", The World Bank Economic Review, Vol. 15, pp. 451-479.

Melitz, J. (2008), "Language and Foreign Trade", European Economic Review, Vol. 52, pp. 667-699.

Moenius, J., Trindade, V., Wu, W. (2009), "The Gravity of the Situation: Prices, Regions, and The Border Puzzle", Working Paper, University of Redlands and University of Missouri.

OECD. (2007), Policy Coherence for Development: Migration and Developing Countries, Paris, Organisation for Economic Co-operation and Development.

Puri, L. (2008), "Assuring Development Gains and Poverty Reduction from Trade: The Labor Mobility and Skills Trade Dimension", Geneva and New York, United Nations Conference on Trade and Development.

Rauch, J. (1999), "Networks versus Markets in International Trade", Journal of International Economics, Vol. 48, pp. 7-35.

Rauch, J. (2001), "Business and Social Networks in International Trade", Journal of Economic Literature, Vol. 39, pp. 1177-1203.

Santos Silva, J., Tenreyro, S. (2006), "The Log of Gravity", Review of Economics and Statistics, Vol. 88, pp. 641-658.

Tinbergen, J. (1962), Shaping the World Economy, New York, The Twentieth Century Fund. UNCTAD/WTO. (2009), World Tariff Profiles 2009, Geneva, UNCTAD.

Zukang, S. (2009), International Migration Trends, Paper presented at Contribution of 
Migrants to Development: Trade, Investment and Development Linkages, Geneva, United Nations Conference on Trade and Development, 29 July. 